\title{
Contaminant transport to public water supply wells via flood water retention areas
}

\author{
D. Kühlers ${ }^{1}$, E. Bethge ${ }^{2}$, G. Hillebrand ${ }^{3}$, H. Hollert ${ }^{4}$, M. Fleig ${ }^{5}$, B. Lehmann ${ }^{3}$, D. Maier ${ }^{6}$, M. Maier ${ }^{1}$, U. Mohrlok ${ }^{2}$, \\ and J. Wölz ${ }^{4}$ \\ ${ }^{1}$ Stadtwerke Karlsruhe GmbH (SWK), Karlsruhe, Germany \\ ${ }^{2}$ Institute for Hydromechanics (IfH), Karlsruhe, Germany \\ ${ }^{3}$ Institute for Water and River Basin Management (IWG), Karlsruhe, Germany \\ ${ }^{4}$ Institute for Environmental Research (IfU), Aachen, Germany \\ ${ }^{5}$ DVGW-Technologiezentrum Wasser (TZW), Karlsruhe, Germany \\ ${ }^{6}$ Heinrich-Sontheimer-Laboratorium (HSL), Karlsruhe, Germany
}

Received: 28 January 2009 - Revised: 16 June 2009 - Accepted: 17 June 2009 - Published: 6 July 2009

\begin{abstract}
The essential processes and mechanisms of the transport of contaminants from a river to a well field via a flood water retention area are presented. The transport is conceptualized as a succession of three phases: (1) contaminant entry into the retention area, (2) passage through the soil zone and (3) transport with the groundwater flow. Depending on the conditions of a given location and on the properties of the contaminants of interest, processes within each transport phase may reduce the concentration of the contaminants at the well field. For the Kastenwoert-Rappenwoert study area, the results of the described processes are shown by chemical and ecotoxicological analyses as well as by numerical modelling. Based on the results of the analyses, it is predicted that some contaminants in the study area will be completely detained along the transport path, while others will be transported as far as the well field, although in significantly reduced concentrations.
\end{abstract}

\section{Introduction}

Along many rivers, flood retention areas have to be built to protect downstream settlements against the impacts of extreme flooding. In these floodplains, riparian aquifers are often used for drinking water production. Consequently, the proximity of retention areas to drinking water production wells may lead to conflicts of interest. Drinking water providers are concerned that river water, which often bears

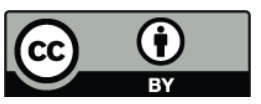

Correspondence to: D. Kühlers

(dirk.kuehlers@stadtwerke-karlsruhe.de) elevated loads of inorganic and organic particle-bound and dissolved contaminants, could be directed through the retention areas toward production wells, decreasing the groundwater quality at the municipal well fields. To predict the magnitude of the effect, an in-depth understanding of the processes and mechanisms active along the transport path of the contaminants is crucial.

\subsection{Contaminant transport}

The transport of the contaminants from the river to a water department's well field via a retention area occurs in three consecutive phases: (1) entry into the retention area, (2) passage through the soil zone and (3) transport with the groundwater flow. For these phases, corresponding conceptual "compartments" can be identified, all of which are depicted schematically in Fig. 1. Depending on the conditions at a given site and on the properties of the contaminants of interest, each of the compartments, the retention area, the soil zone and the aquifer, may act as a barrier, reducing the concentration of the contaminants.

In the first transportation phase, contaminants are conveyed into the retention area and retained within. The transport of dissolved substances may be assumed to be identical to that of conservative tracer compounds for which no reduction in concentration occurs at this stage. Significant concentration effects, however, are observed for contaminants adsorbed to suspended sediments. The transport of sorbed contaminants is strongly dependent on the highly complex depositional processes of sediments within the retention area, which lead to an accumulation at particular locations.

Published by Copernicus Publications on behalf of the European Geosciences Union. 
During the second transport phase, the contaminants pass from the surface of the retention area through the soil zone and into the aquifer. The soil zone reduces the contaminant mass entering the groundwater primarily through the following mechanisms: reduction of the percolation rate, retardation of the contaminants in the soil matrix and microbiological degradation.

The third phase consists of the transport of the contaminants with the groundwater flow. The concentration of contaminants at the production wells can be reduced during transport through the aquifer by the processes of advective transport, dilution, retardation and degradation.

\subsection{Kastenwoert-Rappenwoert study area}

A site-specific examination of the contaminant transport processes and mechanisms presented in the previous section was carried out at the Kastenwoert-Rappenwoert study area, located south of Karlsruhe, Germany. The investigation area is situated on the eastern bank of the Rhine River close to the point where the German Federal States of BadenWuerttemberg and Rhineland-Palatinate border each other and France. It is located within the Upper Rhine Graben, a sedimentary rift basin that is bounded by the raised shoulders of the Vosges Uplands of France to the west and the Black Forest to the east. The study area consists primarily of forest with limited agricultural use and small expanses of open water.

The soil at the site is the product of changing flow and sedimentation conditions during the development of the floodplain. There are significant differences between more elevated areas, where sandy soil predominates and the lowerlying beds of infilled abandoned river channels with their finer sediments. Due to the topography of the retention area, the soil zone thickness varies between approximately 1 and $4 \mathrm{~m}$. In general, the clay and organic carbon content of the soil decreases with depth along the soil profiles (Bechler and Hofmann, 1996).

The aquifer is composed entirely of fluvial sediments of varying thickness. In the study area, the uppermost aquifer, from which the groundwater withdrawal is planned, extends to a depth of about $30 \mathrm{~m}$ and is composed of highly permeable sediments with an average hydraulic conductivity of about $1.5 \cdot 10^{-3} \mathrm{~m} / \mathrm{s}$.

The Rhine River has an average annual discharge of $1250 \mathrm{~m}^{3} / \mathrm{s}$ near the study area $(\mathrm{HVZ}, 2008)$ and its watershed encompasses the entire surrounding region. However, water levels in the Rhine are largely independent of local precipitation because the Rhine derives its water primarily from the Alps. When water levels in the Rhine are high, they have a damming effect on groundwater draining to the river from the surrounding aquifer. Under the influence of the local reversal in the groundwater gradient, the groundwater flows northward along secondary streams until it eventually empties into the Rhine further downstream. Contaminants found in sig-

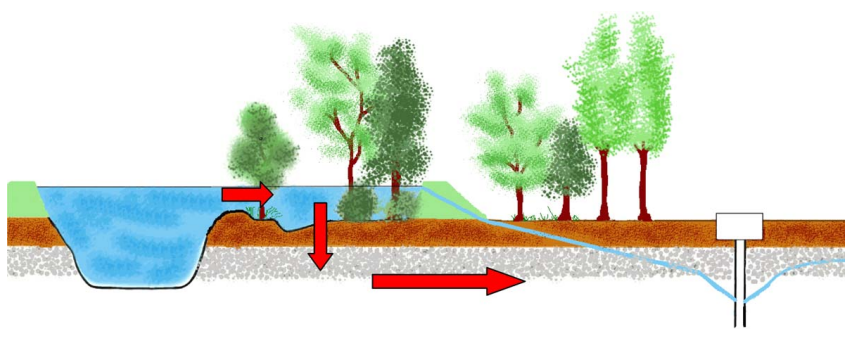

Fig. 1. Contaminant transport from a river to a well field via a flood water retention area.

nificant concentrations in the Rhine near the study area include highly adsorptive organic compounds like HCB, PAH and PCB (Maier et al., 1998; Kosmehl et al., 2004, 2007), as well as highly mobile organic compounds like EDTA, pharmaceutical residues and X-ray contrast agents (Fleig et al., 2008).

The study area, depicted in Fig. 2, contains the planned "Bellenkopf/Rappenwoert" flood water retention area. With an areal extent of $5.1 \cdot 10^{6} \mathrm{~m}^{2}$ the retention area will provide a flood water storage volume of $14 \cdot 10^{6} \mathrm{~m}^{3}$. The retention area is one component of Baden-Wuerttemberg's Integrated Rhine Programme (IRP), which includes 13 flood water retention areas along the Rhine River between Basel, Switzerland, and Mannheim, Germany. The Bellenkopf/Rappenwoert area has, however, also been designated as part of the wellhead protection zone for the Kastenwoert well field (maximum extraction of 7.4 million $\mathrm{m}^{3} / \mathrm{a}$ ) which the local water department plans to build adjacent to the planned retention area site. Planning for both projects is nearing completion. Extensive chemical and ecotoxicological analyses of the suspended load in the river, soil and groundwater were conducted to determine the status quo in the study area in each of the presented compartments. Using this baseline, numerical models were applied to predict the interactive effect of the projects, neither of which has yet been realised. Together the results of the analyses and the modelling were used to characterise the three compartments of the transport path.

\section{Phase 1: entry of contaminants into the retention area}

\subsection{Characterization}

The transport of contaminants into the retention area and their retention constitute the first phase of the contaminant transport. The contaminants reach the retention areas either in dissolved form or adsorbed to suspended sediments. Substances dissolved in the water of the flood wave are transported like a conservative tracer compound. The suspended sediments, that often hold adsorbed contaminants, behave differently depending on their size and weight. Therefore, to study and evaluate the first phase of the contaminant 
transport, in-depth knowledge about the advective and diffusive transport mechanisms as well as the deposition of suspended sediments within the retention area is crucial.

A series of field measurements were conducted near the study area to get an impression of deposition patterns on the inundated floodplains. Sediment traps consisting of artificial turf mats were used to determine the amount of sediments deposited during two flood events, a smaller one in September 2006 and a larger one in August 2007. As an example, Fig. 3 shows a cross-section of the floodplain with the approximated peak water levels for both flood events and the average amounts of sediment deposited at three locations of increasing distance from the river main channel. Firstly, Fig. 3 illustrates that higher flood events yield higher sediment deposits, but no direct proportionality is found. Furthermore, comparing different values of the same flood event, higher inundation heights increase the amount of deposited sediments. This effect becomes particularly evident for low relative inundation heights.

The corresponding grain size distribution of the deposits is depicted in Fig. 4. The average grain size decreases with increasing distance from the river main channel. This is due to the reduced transport capacity of the overbank flow. Coarser sediment is deposited soon after reaching the overbank area. Finer sediments are more uniformly distributed throughout the floodplain. (This is supported by additional data which are not presented here.) On the other hand, the comparison of the two flood events shows that the grain size distribution at one location does not vary strongly for different flood events. The main difference can be found with the clayey fraction. For the 2007 flood event, the proportion of deposited clay sediment is higher than for the 2006 flood event, probably due to the longer duration of floodplain inundation (about 7 days in 2007 instead of about 2 days in 2006) rather than to the higher flood level.

Based on the field study and on an additional literature review (cf. e.g. Asselman and Middelkoop, 1995; He and Walling, 1997; Howard, 1992; Walling and Bradley, 1989), the following conclusions on the most important influencing factors of the deposition patterns of suspended sediments on floodplains can be drawn:

- Local suspended sediment concentrations significantly influence the amount of deposited sediment. High concentrations lead to high deposition rates.

- Grain sizes influence suspended load and settling velocities. Coarser sediments deposit on the floodplain close to the river channel. Finer fractions are more uniformly distributed within the suspension across the floodplain.

- The total deposition is directly proportional to the duration of the specific flood event for near-steady conditions. For unsteady conditions, high local inundation heights at a given site generally correspond to long inundation periods. Thus, high local inundation heights

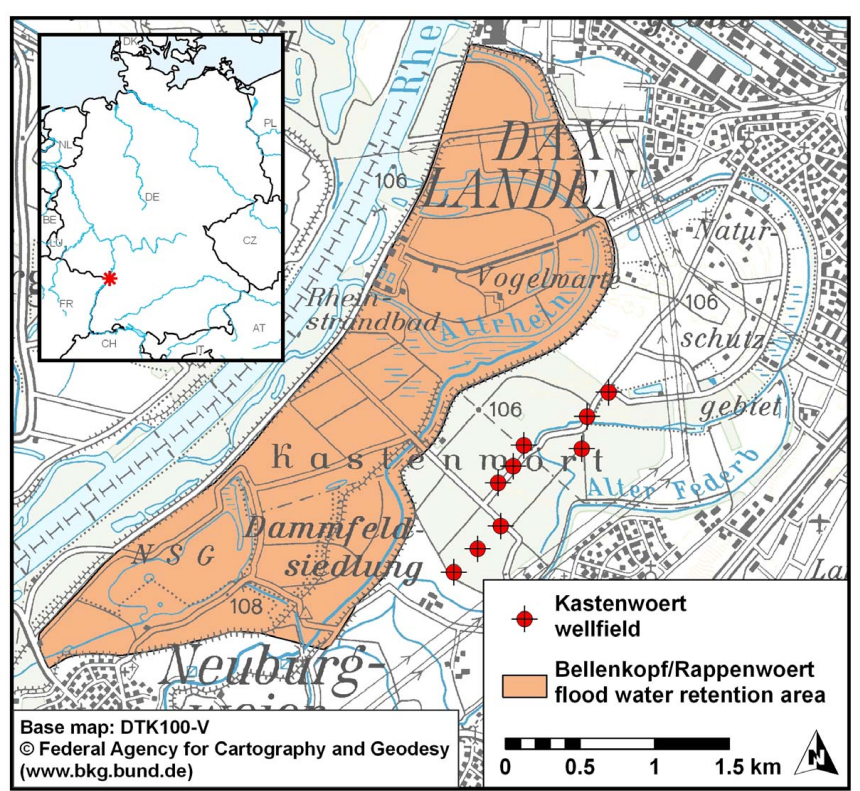

Fig. 2. The Kastenwoert-Rappenwoert study area.

usually correlate with increased deposition. Trapping effects of flood water in local depression areas also substantially increase the amount of deposited sediments.

- Local flow velocities influence the deposition rates by reducing the probability of sediment deposition for high velocities. However, there is evidence that a definite critical value above which no deposition occurs does not exist in reality as was believed in the past (Haralampides et al., 2003; Krishnappan and Engel, 1997; Krone, 1993; Kuijper et al., 1991).

\subsection{Chemical analysis}

To predict the concentration of contaminants that could be extracted at the planned well field, it is important to identify the substances that are present in the river water. A comprehensive data set measured by governmental institutions and water suppliers were analyzed to get an overview of the current water quality situation in the Upper River Rhine. Special attention was given to measurements taken during high flow events. The most important groups of chemical substances regularly found dissolved in water samples from the Upper River Rhine are:

- Total and surrogate parameters with organic carbon (DOC), organic sulphur (AOS) or organic halogens (AOX);

- Complexing agents (NTA, EDTA, DTPA); 


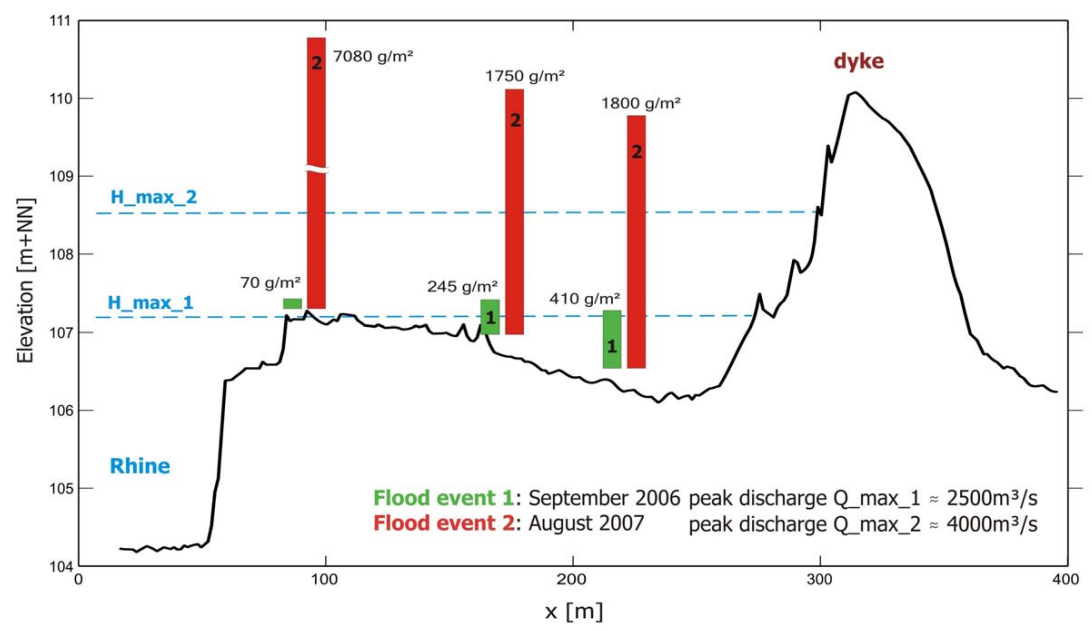

Fig. 3. Deposited sediments of two flood events at a cross-section of the floodplain of the Rhine River near Neuburgweier, Germany. The peak flood height is depicted for both events.

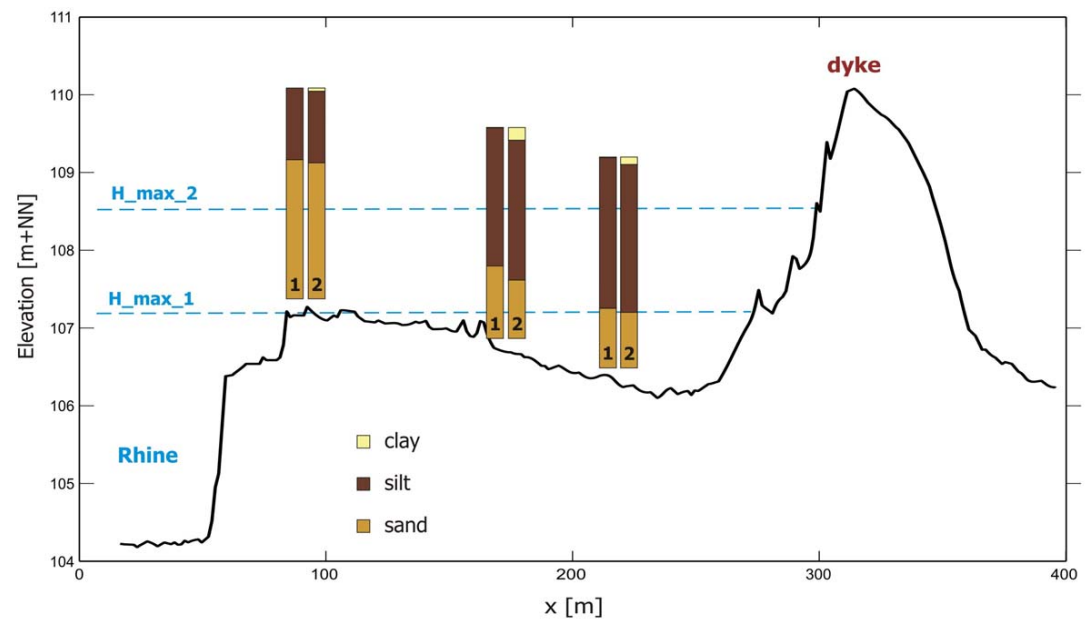

Fig. 4. Grain size distribution of deposited sediments of two flood events at a cross-section of the floodplain of the Rhine River near Neuburgweier, Germany. The peak flood height is depicted for both events. The bars show the proportions of the respective grain size classes.

- Pesticides and their metabolites ( $N, N$-dimethylsulfamide); and

- Xenobiotic organic compounds (chlorinated benzenes, MTBE).

Most of these substances are polar and often quite persistent, so it can be assumed that they potentially infiltrate into the groundwater.

Organic substances with a high $\mathrm{K}_{O W}$, like Hexachlorbenzene (HCB), polychlorinated biphenyls (PCB) and polynuclear aromatic hydrocarbons (PAH), are almost exclusively found adsorbed to suspended matter. Therefore, suspended sediments were also analysed.

Suspended sediments were collected on deposition with turf mats as described in Sect. 2.1 during the flood event in
August 2007 at various distances from the Rhine River. After lyophilisation the amount of different adsorbed organic compounds were determined.

From the bank of the Rhine River towards the dyke the amount of the indicator compound HCB decreases by more than $90 \%$. The concentrations of other compounds decrease by half at locations further away from the river. Only AOX and the carbon fraction increase with distance from the Rhine River.

\subsection{Ecotoxicological analysis}

Suspended sediment are known to provide huge surfaces and binding sites for organic and inorganic compounds (Hollert et al., 2007; Kosmehl et al., 2007). Furthermore, most rivers 
are (highly) loaded with contaminants of various sources, at least as a legacy of the past (Stronkhorst and van Hattum, 2003). While sediments may act as contaminant sinks under normal hydrological conditions, (extreme) flood events cause sediment erosion and, thus, sediments and contaminants may be released into the water column (Hilscherova et al., 2007; Hollert et al., 2000, 2003; Wölz et al., 2008). Subsequently, they may pose a threat to organisms in the aquatic and inundated terrestrial environment, but also to human interests and health, e.g. regarding drinking water supply (Maier et al., 2006).

Thus, the recent ecotoxicological study focused on the evaluation of impacts by particle-bound organic compounds. In order to evaluate the risk of particle translocation from the river on inundated sites, e.g. retention areas, a battery of in vitro biotests comprising several ecotoxicological endpoints was applied. For instance, the acute toxic Neutral Red retention assay (cytotoxicity; Babich and Borenfreund, 1992; Klee at al., 2004; Keiter et al., 2006) and the mechanism specific 7-ethoxyresorufin- $O$-deethylase (EROD) assay (Ah receptor mediated activity; Behrens et al., 1998; Keiter et al., 2008; Kennedy et al., 1996; Lorenzen and Kennedy, 1993) were used. Under normal hydrological conditions, some samples of suspended sediments indicated temporarily elevated cytotoxic effects, while most samples were only minimally toxic. On the other hand, EROD inductions were mostly increased and some samples clearly indicated significant effects that could not be correlated with any other parameter.

The sediments collected with turf mats during the flood event in August 2007 were also examined using effectdirected analysis. Combining fractionation methods (in cooperation with W. Brack, Helmholtz Center for Environmental Research Leipzig), cell-based in vitro biotests and chemical analysis were applied to identify effect causing compounds. Fractions containing PAHs and more polar to polar compounds were found to be most toxic (Brack et al., 2005).

In conclusion, based on the fact of particle translocation in the retention area, a contamination of the inundated site by primarily bound compounds has to be considered, unless measures may diminish particle entry or guarantee short residence times.

\subsection{Modelling}

In order to determine the deposition patterns within the planned retention area, input data about hydrologic, hydraulic and sediment parameters is necessary. Water levels and local flow velocities were determined by a 2-D hydrodynamic numerical model for different flood scenarios. The output data from this model was converted into raster-based datasets. Several deposition models from the literature with different approaches were tested with the field data from the investigated flood events and then applied to the retention area. The results will not be presented in this article, but some essential findings should be mentioned:

- Advection appears to be a significant process for the floodplain in question, mainly due to the dominant flow through topographic depressions, side channels or ditches on the floodplain, which are activated during flood events.

- Pure diffusion models, which do not account for any advection across the floodplain, significantly underestimated the sediment deposited at greater distances from the main river channel (e.g. Pizzuto, 1987). Side channels could be incorporated in the model as additional sediment sources to at least partly compensate for this effect.

- Each of the investigated models uses several empirical parameters, which greatly influence not only the amount of deposited sediments but also the deposition pattern. The determination of those empirical parameters is challenging, a factor which must be taken into account when evaluating the results of the simulations.

- While hydraulic parameters may be determined with sufficient accuracy, reliable information on sediment characteristics during flood events are difficult to obtain. This should be considered, as model results prove to be highly sensitive to variations of model input parameters (especially water levels and sediment concentrations).

\section{Phase 2: passage through the soil zone}

\subsection{Characterization}

As described in the previous section contaminants can reach the ground surface of the retention area in dissolved form or sorbed to settled flood water sediments. Because of the filtering effect of the soil matrix, particle-bound contaminants are mainly retained at the soil surface. Therefore, a considerable mass flux of dissolved contaminants to the aquifer is more likely. The infiltration of dissolved organic contaminants into the soil zone is determined by the seepage rate. Preferential pathways (macropores) can allow soil water and solutes to by-pass the soil matrix and travel quickly into deeper soil regions (Beven and Germann, 1982; Wang and Narasimhan, 1985).

Within the soil zone compartment, the contaminant mass flux into the aquifer is reduced by three processes. First, the infiltration of contaminants into the soil zone is decreased. Contaminated sediments are mainly retained at the soil surface, and additionally the infiltration of dissolved contaminants is decreased by the low permeable floodplain soil. Secondly, the transport of infiltrated contaminants within the soil 
zone is retarded by adsorption to the soil matrix. As a third effect, microbes act to degrade the infiltrated contaminant mass. The mechanisms can influence each other. A low infiltration rate reduces the contaminant input into the soil zone and slows down the transport velocity towards the aquifer. This, in turn increases the travelling time of contaminants, thereby supporting the microbial degradation.

The input of dissolved organic contaminants into the soil zone of the retention area is determined by the infiltration rate of the flood water. This infiltration generates water flow through the soil zone which is affected by several changes in the hydraulic conditions during a flood event. For the soil zone, three consecutive stages with different hydraulic conditions can be identified during a flooding period:

- Stage 1 (S1): Infiltration of flood water into unsaturated soil.

- Stage 2 (S2): Infiltration of flood water under saturated conditions.

- Stage 3 (S3): Drainage of soil after the flood event.

The essential factors controlling the mass input into the soil zone are the hydraulic properties of the soil (average hydraulic conductivity) and the characteristics of the flood event (flooding height and duration). The hydraulic gradient between surface and groundwater plays a major role for these processes. It evolves towards lower values during the flooding period and shows large spatial variability depending on the elevation of the groundwater table and the thickness of the soil zone. Additionally, steep hydraulic gradients often occur at the inland bank of a retention area during a flood. Within a highly conductive soil zone, the resulting seepage rate will yield a strong mass input into the soil zone there.

The mass output to the aquifer is controlled by the transport velocity within the soil and the storage capacity of the soil zone. The transport velocity is controlled by the average seepage velocity and the retardation by sorption to the soil matrix. The sorption of organic contaminants to the soil matrix is related to the soil organic carbon content and the octanol-water partitioning coefficient $\mathrm{K}_{O W}$. The storage capacity of the floodplain soil is a function of those two properties and the soil thickness. The highly variable properties of the floodplain soils and the hydraulic conditions within the retention area have to be taken into account to calculate the contaminant mass flux through the soil zone to the aquifer.

\subsection{Chemical analysis}

Soil was sampled to a depth of up to $90 \mathrm{~cm}$ at two locations. The first site, located directly along a Rhine backwater, is periodically inundated. The second, situated $15 \mathrm{~m}$ inland is only inundated during extreme flood events. The concentrations of $\mathrm{HCB}, \mathrm{PCB}$ and $\mathrm{PAH}$ at the site near the river were five times higher than the values from the second site and unlike at other sites increase with depth. The backwater site, an infilled oxbow, was filled with contaminated sediment over time. Decreases in sediment contaminant loads in recent decades led to the observed concentration depth profile. The observed increase is therefore clearly not to be explained by transport processes in the soil zone. In conclusion, the repeated deposition of contaminated river sediments at frequently inundated sites is confirmed by the results of the chemical analyses.

The remobilisation of sediment-sorbed pollutants was examined in batch experiments with a soil-to-water-ratio of one to ten. Only a few chemicals (HCB, 1,2,3-trichlorbezene) showed even small reductions.

In another series of experiments, soil from the study area was used to fill small columns through which water containing a known concentration of an organic pollutant was percolated. The outflow concentration was determined at short time intervals. Most contaminants broke through very rapidly, within one to two days, appearing at the column outlet at the same concentration as at the input. The experiments thus demonstrated that not all pollutants could be retained by the soil or degraded by microorganisms.

\subsection{Ecotoxicological analysis}

In Sect. 2.3 it was shown that contaminants, once entering the retention area and passing the first compartment, increase the contamination risk of the following compartments soil and groundwater. Thus, the toxic effects and displacement of particle-bound compounds were assessed comparing soil samples of periodically inundated sites, including those described in Sect. 3.2, and non-inundated sites at the planned "Bellenkopf/Rappenwoert" retention area.

The assessment of soil profiles with a depth of $90 \mathrm{~cm}$, separated in sub-samples, allowed the determination of total effects and the effect course in each profile by applying the in vitro biotests mentioned above. While cytotoxic effects were minor at nearly all sites, EROD activities were elevated at some sites and significantly increased in surface depressions, containing accumulated deposited sediments. In addition, the Ames Fluctuation assay (Perez et al., 2003) was applied and indicated considerable mutagenic effects, according to the highly effective samples identified in the EROD assay. At each site with exception of the backwater site described in Sect. 3.2, it could be shown that toxic effects decreased from the surface to the lowest soil layer assessed. Commonly, these findings are due to the high contents of humic compounds in the upper soil layer, providing huge binding surfaces. In particular at river banks, lower soil layers consist of large grained compounds as gravel and, thus, provide significantly less binding sites (Fernandez-Galvarez, 2007), resulting in a decrease in toxic effects.

Concluding, at least in depressions at periodically inundated sites, toxic effects were comparable to effects detected in the first compartment. Thus, SPMs displaced in (extreme) 
flood events and deposited on floodplains accumulate and act as contaminant sinks that may subsequently turn into sources, potentially releasing hazardous compounds into the soil. In absence of mechanisms to reduce contaminant deposition on floodplains/retention areas these aspects should be considered.

\subsection{Modelling}

To calculate the transport of dissolved organic contaminants through the soil zone of the retention area to the aquifer, a one-dimensional contaminant transport model (FWinf) was developed (Bethge and Mohrlok, 2008). The transport processes during a flood event were described using a time efficient analytical modelling approach. The relatively short computing time allowed the mass flux to the aquifer to be calculated for a large number of locations, thus accounting for the spatial variability of the floodplain soils.

In the model FWinf, the soil zone was represented with a two-layered soil profile, where a loamy topsoil overlies a sandy subsoil. The presence of macropores is considered for the topsoil only. To calculate the transport of the infiltrated contaminants through the soil zone, advective transport of the contaminants with the soil water movement is considered. The by-pass flow through macropores in the topsoil was taken into account by a simple macropore bundle approach (Chen and Wagenet, 1992). The retarding effect of the contaminant sorption to the soil matrix was simulated using a retardation factor, whereas contaminant mass degradation was implemented with a first order kinetic model.

The mass balance model FWinf was applied to the planned "Bellenkopf/Rappenwoert" flood water retention area. Field infiltration experiments have been conducted to estimate the macropore porosity of the topsoil. Soil samples were taken from the field to determine the saturated conductivity and water retention parameters. Additionally, the organic carbon content was determined at different depths. The soil map and land use categories (forestry, agricultural, open water bodies) were used to regionalise these data over the floodplain and to outline simulation units that were used to calculate the one dimensional contaminant transport within the soil zone.

To calculate the mass flux through the soil zone a flooding scenario with a 20 year annuality was chosen. For the properties of the contaminant in the flood water an average sorptivity $\left(\mathrm{K}_{O W}=0.3\right)$ and degradation rate $(\lambda=$ $1.1 \cdot 10^{-7} 1 / \mathrm{s}$ ) were chosen (similar to the pharmaceutical carbamazepine). The concentration in the flood water was set to $1.0 \cdot 10^{-3} \mathrm{~kg} / \mathrm{m}^{3}$.

In Fig. 5 the areal distribution of the contaminant mass flux to the aquifer is shown for the "Bellenkopf/Rappenwoert" retention area. Near the inland embankment drainage measures to control the inland groundwater level establish a large hydraulic gradient between surface water and groundwater head. As a result, almost $99 \%$ of the mass output from the soil zone into the groundwater occurs within $200 \mathrm{~m}$ of the in-

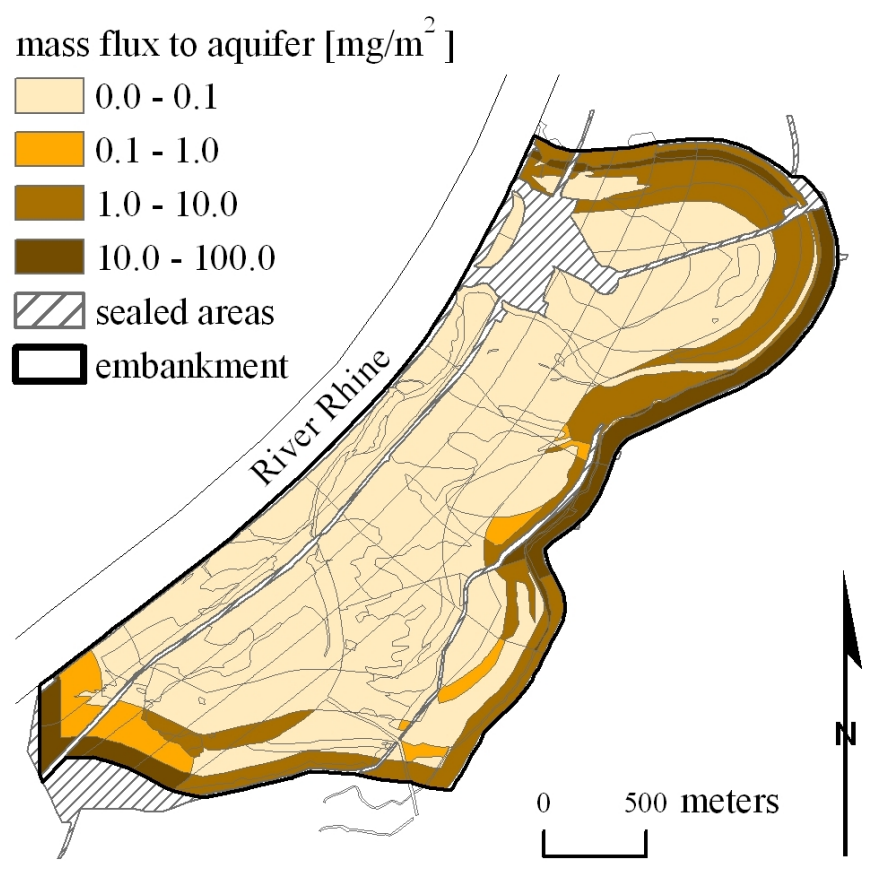

Fig. 5. Areal distribution of the calculated contaminant mass flux to the aquifer

land dykes. The highest contaminant mass fluxes are found where high seepage rates coincide with small contaminant storage capacity of the soil zone (small thickness of the soil zone, low organic carbon content).

In Fig. 6 the calculated overall mass balance for the soil zone of the study area is shown for the different flow stages of the seepage rate (Sect. 3.1). Mass input $\left(\mathrm{M}_{\mathrm{in}}\right)$ is observed during the flow stages $\mathrm{S} 1$ and S2, mass flux into the groundwater $\left(\mathrm{M}_{\text {out }}\right)$ takes place during flow stages $\mathrm{S} 2$ and $\mathrm{S} 3$. The highest mass input and output are observed in flow stages S2. For the given contaminant properties, the mass storage in the soil $\left(\mathbf{M}_{\mathrm{soil}}\right)$ and mass degradation $\left(\mathbf{M}_{\mathrm{deg}}\right)$ are small compared to the mass inflow and outflow.

\section{Phase 3: groundwater flow}

\subsection{Characterization}

The third phase of the contaminant transport to the well field of a water department is the transport with the groundwater flow. A reduction of concentrations in the production wells occurs as the result of mechanisms of advective transport, dilution, retardation and degradation.

The contaminants are transported primarily advectively with the groundwater flow. Therefore, even if they enter the groundwater, they can only reach the production wells if the groundwater gradient in the extremely transient flow field is oriented towards the production wells for a sufficiently long time. If instead the groundwater gradient is directed 
primarily towards the river, the appearance of a significant concentration of contaminants in the production wells can be excluded. Therefore, water that infiltrated into the aquifer during flooding of the retention area, can, in most cases, only reach the well field if the well field's zone of contribution overlaps the retention area under average hydrologic conditions. If there is no overlap, the groundwater quality at the well field will be unaffected by the retention area in most cases.

Figure 7 depicts an idealized well field with a catchment area which overlaps with the flood water retention area and even extends to the river at average hydraulic conditions. In such a case, even under average hydraulic conditions, the groundwater extracted at some production wells will contain a significant percentage of infiltrated river water. When the retention area is flooded with river water, the gradient between the retention area and the well field will increase and thereby directly increase the percentage of river water at the municipal wells. Furthermore, during flooding, river water will infiltrate in the aquifer mainly at the edge of the retention area, as discussed in Sect. 3.4 and depicted in Fig. 8. After flooding, this infiltrated water will be transported by the normal groundwater flow to the production wells and will eventually reach them, as much as years after the flooding event, depending on the velocity of the groundwater flow.

The concentration of substances from the river that reach the pumping wells will be reduced by dilution. First, it must be noted that the volume of the river water entering the aquifer during flooding of the retention area will generally be much smaller than the volume of groundwater already in the aquifer. On its way towards the extraction well, the water and the substances it carries with it will be mixed with the groundwater by dispersive processes, reducing the concentrations of contaminants significantly. An additional dilution process takes place in the withdrawal wells and in the water treatment plant. The pumping wells of the water works draw groundwater from both the retention area side and the inland side. Under average hydraulic conditions, when the retentions area is not flooded, considerably more water from inland reaches the pumping wells because of the low groundwater gradient between the well field and the stagnation point, which lies in direction of the retention area. Furthermore, several of the withdrawal wells often extract no infiltrated river water (Figs. 7 and 8). Both mechanisms strongly reduce the concentrations of infiltrated substances from the retention area at the water works.

Retardation and degradation can further reduce contaminant concentrations at the well field, but both mechanisms are highly dependent on the properties of the substance of interest. Certain substances, such as many X-ray contrast agents, will neither be retarded nor degraded in an aquifer.

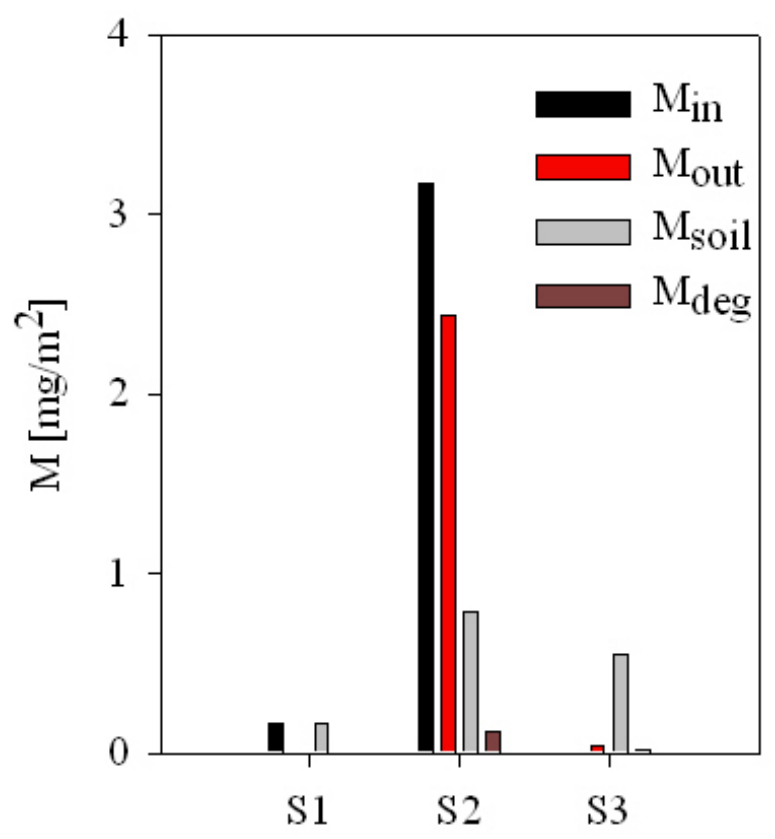

Fig. 6. Calculated average contaminant mass fluxes for each stage of infiltration into the soil zone.

\subsection{Chemical analysis}

The analysis of ground water samples collected following the flood event in August 2007 revealed changes in concentrations of chemical compounds directly associated with river water. In particular, increases in the concentrations of complexing agents and fuel additives as well as dissolved oxygen, pharmaceutical products and a pesticide metabolite were observed.

The analyses confirmed that inputs of river water to the aquifer occurred not only through infiltration at the river bank, but also at a backwater site. The tests established that dissolved organic contaminants were able to pass through the soil zone and enter the aquifer.

The ability of microbial organisms to degrade organic compounds strongly influences the amount of pollutants that reach the drinking water wells. Because the planned well field will substantially alter the groundwater flow regime, it was impossible to examine changes in contaminant concentrations in field studies. Therefore laboratory experiments were carried out.

In a series of tests, defined amounts of typical pollutants were added to Rhine water which was then circulated in a closed experimental plant. The tests showed that the concentrations of some pharmaceuticals and organic pollutants were reduced by less than $50 \%$ even after thirty days and were therefore defined as substances of concern for drinking water suppliers. It must be concluded, that transport through the aquifer cannot protect the well field against some persistent organic pollutants. 


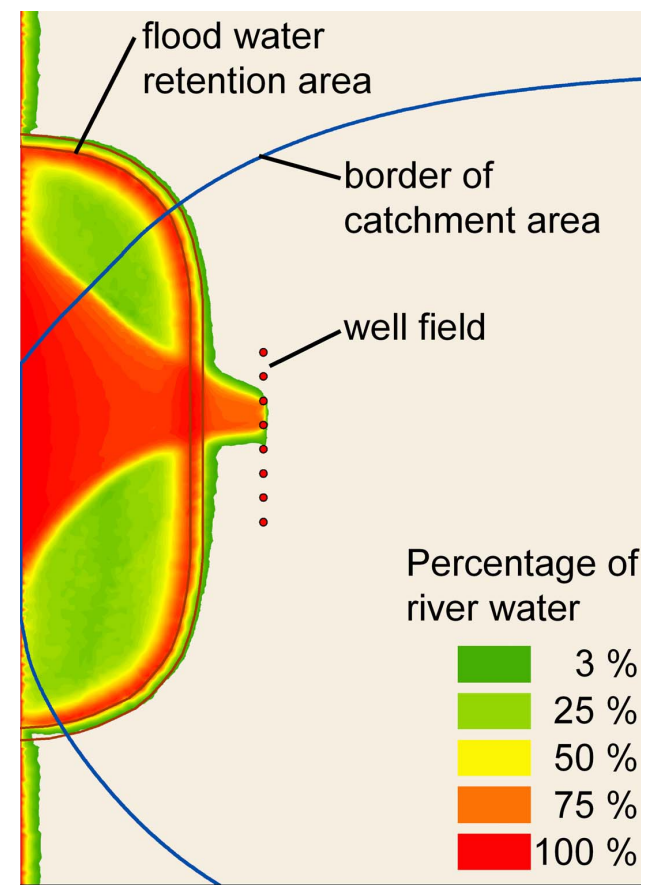

Fig. 7. River water in the aquifer before flooding of the retention area.

\subsection{Ecotoxicological analysis}

While Sects. 2.3 and 3.3 introduced the background and outcomes regarding contaminant entry with deposition/displacement through the soil, the focus here is to determine whether contaminants may pass through the soil layer and enter the drinking water aquifer.

Neither Ah receptor agonist (EROD assay) nor mutagenic activity (Ames Fluctuation assay) indicated significantly increased activities, nor could cytotoxicity be determined. However, endocrine activity mediated through the human estrogen receptor (ER) in the YES assay (Routledge and Sumpter, 1996) could be measured, showing elevated endocrine effectiveness for some of the samples and considerable fluctuations at different sampling times. Nevertheless, the data reflected a time-effect correlation, at least, with groundwater sampled at short intervals following the more intense Rhine flood $(\approx$ HQ10) in August 2007. So far, there are no data available which would indicate a flood dependent increase; and maybe only a temporal coherence is given.

As endocrine active compounds seemed to be the most relevant groundwater contaminants at the site, effect-directed analysis (Lübcke-von Varel et al., 2008) was applied to identify relevant inducers. Furthermore, fractionation was performed with flood SPMs and highly effect-causing soil. Endocrine activity was measured in each sample, at least constituting to a considerable extent to effects in groundwater. Additional chemical analysis to identify effective compounds is underway.

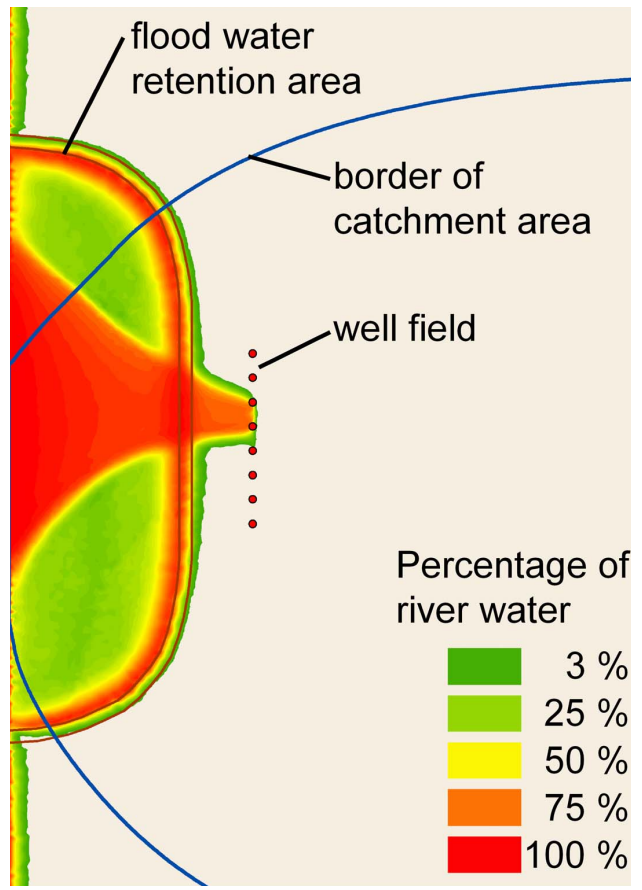

Fig. 8. River water in the aquifer after flooding of the retention area.

In conclusion, previously effective compound categories and ecotoxicological endpoints were no longer relevant in the groundwater, while endocrine activity was detectable. Furthermore, activities were measured in sample fractions of the other compartments. Thus, although the origin of the measured ER agonist activities remains so far unclear, considering the complete ecotoxicological assessment an impact of particle-bound compounds to drinking water supply cannot be excluded. Further research has to focus on the identification of effect-causing compounds and will be completed following this project.

\subsection{Modelling}

For the Kastenwoert-Rappenwoert study area a numerical groundwater flow and transport model was constructed to predict the influence of the planned retention area on the percentage of Rhine water in the groundwater extracted at the well field. The 3-D finite element model was constructed using the groundwater modelling program FEFLOW from DHI-WASY. The model area covers an $11 \mathrm{~km}$ stretch of the eastern Upper Rhine valley (a total of approximately $120 \mathrm{~km}^{2}$ ). The large model area was necessary in order to include the whole catchment area of the water work. The spatial discretization of the model, in particular near the Rhine, had to be very fine in order to ensure stable mass transport calculations. In total, the groundwater model contained 529,060 elements (75,580 per layer) and 304,904 nodes (38,113 per slice). A simulation time of 46 years was 
chosen (from January 1960 to December 2005), the longest time period for which data were available. This made it possible to examine long-term developments. The lengths of the time steps, which varied between a few minutes to 7 days, were automatically selected by the program system by the predictor-corrector scheme (AB/TR).

In order to prepare the model for transport simulation, the Dirichlet boundary condition simulating the Rhine River was assigned a mass concentration of $100 \mathrm{mg} / \mathrm{l}$. The water infiltrated through the retention area was given the same value. Thereby the percentage of the Rhine water in the aquifer during the transport simulation could very simply be observed and illustrated. As some of the substances in the river water, for example X-ray contrast agents, are neither degraded nor retarded in the groundwater flow, these processes were not included in the transport simulation. On a standard PC, the calculation of a complete transport scenario took about 3 weeks.

Figure 9 illustrates the ratio of Rhine water to groundwater in the planned well field as calculated with the numerical groundwater model described here. The red line illustrates the percentage of Rhine water in a scenario in which the municipal wells start pumping in 1960 and pump consistently and steadily for the next 46 years at a combined rate of 7.4 million $\mathrm{m}^{3} / \mathrm{a}$. The retention area is not active in this scenario. The percentage of Rhine water in the extracted groundwater lies between 5 and $10 \%$ in this scenario. The green line shows the fraction of Rhine water in the planned water works in a scenario in which both the wells and the retention area are brought online in 1960. Consistent with historical Rhine water levels measured during that period, about 50 flood events, some of them quite small, were simulated across the retention area. The repeated flooding of the retention area over the course of the simulation period raises the percentage of Rhine water in the extracted groundwater by about 5 to $10 \%$. Following the most significant flood event of the observation period, which occurred in 1999, the percentage of Rhine water rises by as much as $15 \%$ to compose about one quarter of the extracted groundwater.

The simulation results were entirely consistent with the mechanisms described in Sect. 4.1. During the flood events, peaks in Rhine water input are observed and repeated flooding of the retention area leads to an overall increase of the percentage of Rhine water in the pumping wells of the water works in the long term. Due to dilution effects, the probability is very high that the percentage of Rhine water extracted at the water work will remain far less than $50 \%$, despite the proximity of the retention area.

\section{Discussion and conclusion}

The transport of contaminants from a river to a well field via a flood water retention area is affected by the processes and mechanisms occurring in the three compartments: retention area, soil zone and aquifer.

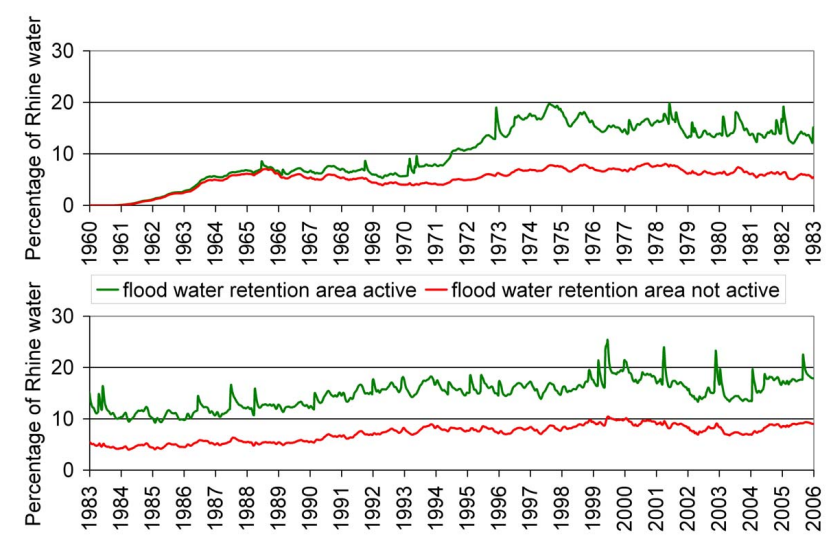

Fig. 9. Result of the numerical groundwater modelling showing the ratio of Rhine water to groundwater at the planned well field.

The first compartment is chiefly characterized by the sedimentation of suspended matter within the flood water retention area. Generally, the concentrations of dissolved contaminants are unaltered by the processes in the first compartment. Contaminants sorbed to suspended matter, on the other hand, are significantly affected, as they will be deposited with the suspended matter.

The chemical and ecotoxicological analysis of suspended matter in the Rhine River show significant presence of contaminants. The same contaminants and ecotoxicological effects could be detected in the upper part of the soil layer of several periodically inundated sites, with intensities varying from site to site. Thereby, the result of the variations in the highly complex depositional processes of the sediment within the retention area could be demonstrated. Numerical models can be applied successfully to improve the prediction of deposition patterns, which in turn define locations within the retention area where contaminants will accumulate.

The second compartment is the soil zone. Its effect on the contaminant mass flux to the aquifer is mainly determined by the properties of the soil and the contaminant as well as the flood event characteristics. The variability of soil properties and hydraulic conditions within the retention area leads to distinct differences of the soil zone's ability to prevent a contaminant input into the aquifer. Applying the contaminant transport model FWinf on the KastenwoertRappenwoert study area, the highest contaminant mass fluxes of dissolved organic contaminants into the aquifer are calculated for low lying soils in the near dyke area with a low organic carbon fraction.

Presently, only a small section of the floodplains directly adjacent to the Rhine River is inundated during floods. The chemical and ecotoxicological analysis of the areas subject to inundation have revealed high concentrations of sorptive contaminants and significant ecotoxicological effects in the upper part of the soil layer, while the lower part of the soil 
zone and the groundwater were free of sorptive contaminants and any significant ecotoxicological effects. It may, therefore, be concluded that the storage capacity of the floodplain soil is sufficient for the current mass input to completely retain sorptive contaminants. The contaminants still found in the groundwater are known to be highly persistent and mobile and thereby had evidently been able to pass through the soil zone or river bank without being significantly affected. However, these substances were found to show no ecotoxicological effects.

In the third compartment, the contaminants are transported with the groundwater to the well field. In most cases contaminants from the river can only reach the production wells if the catchment area of the well field at average hydraulic conditions overlaps with the flood water retention area. In this case, the concentrations of the contaminants are significantly reduced on their way in the aquifer by dilution, and sometimes additionally by microbiologic degradation and retardation.

Regarding the low flow velocities of the groundwater in the study area, it has to be concluded that the organic contaminants recently found in the groundwater have partially been present in the aquifer for several years. Therefore it must be assumed that, given the groundwater flow calculated by the numerical aquifer simulation, these substances would be able to reach the planned well field even after very long transit times.

Using numerical modelling of the study area, it was predicted that some contaminants found in the Rhine River, including HCB, PAHs or PCBs, which are mostly adsorbed to suspended matter, will probably be completely retained within the transport path, while others, like EDTA or X-ray contrast agents, which are highly mobile and persistent, will most likely travel to the well field, although in significantly reduced concentrations.

Acknowledgements. This paper presents results from the HoT joint research project, which received financial support from the German Federal Ministry of Education and Research (BMBF) and was part of the German national research programme "Risk Management of Extreme Flood Events" (RIMAX).

Edited by: K. Günther

Reviewed by: K.-E. Lindenschmidt and another anonymous referee

\section{References}

Asselman, N., Middelkoop, H.: Floodplain sedimentation: quantities, patterns and processes, Earth Surf. Proc. Land., 20, 6, 481499, 1995

Babek, O., Hilscherova, K., Nehyba, S., Zeman, J., Famera, M., Francu, J., Holoubek, I., Machat, J., Klanova, J.: Contamination history of suspended river sediments accumulated in oxbow lakes over the last 25 years, J. Soils Sediment, 8, 165-176, 2008.
Babich, H. and Borenfreund, E.: Neutral Red assay for toxicology in vitro, in: In vitro methods of toxicology, CRC - Press, Boca Raton, Florida, USA, 237-251, 1992.

Bechler, K., Hofmann, B.: Bodenkundliche Untersuchungen im Bereich des geplanten Polders Kastenwört/Bellenkopf, Stadtwerke Karlsruhe, Karlsruhe, Germany, Arbeitsbericht 092/96, 129 pp., 1996.

Behrens, A., Schirmer, K., Bols, N. C. and Segner, H.: Microassay for rapid measurement of 7-ethoxyresorufin- $O$-deethylase activity in intact fish hepatocytes, Mar. Environ. Res., 46, 369-373, 1998.

Bethge, E. and Mohrlok, U.: Uncertainty assessment for contaminant leaching from flood water retention areas, in: Calibration and Reliability in Groundwater Modelling, Credibility of Modelling, IAHS Publication, 320, IAHS Press, Oxfordshire, Great Britain, 27-33, 2008.

Beven, K. J. and Germann, P.: Macropores and water flow in soils, Water Resour. Res., 18, 1311-1325,1982

Brack, W.: Effect-directed analysis: A promising tool for the identification of organic toxicants in complex mixtures?, Anal. Bioanal. Chem., 377, 397-407, 2003.

Brack, W., Schirmer, K., Erdinger, L. and Hollert, H.: Effectdirected analysis of mutagens and ethoxyresorufin- $O$-deehtylase inducers in aquatic sediments, Environ. Toxicol. Chem., 24, 2445-2458, 2005.

Chen, C. and Wagenet R. J.: Simulation of water and chemicals in macropore soils, I, Representation of the equivalend macropoe influence and its effect on soil-water flow, J. Hydrol., 130, 105126, 1992.

Fernandez-Galvez, J., Barahona, E., Iriarte, A., and Mingorance, M. D.: A simple methodology for the evaluation of groundwater pollution risks, Sci. Total Environ., 378, 67-70, 2007.

Fleig, M., Brauch, H.-J., and Kühn, W.: Wesentliche Ergebnisse aus dem AWBR-Untersuchungsprogramm 2007, in: AWBR Arbeitsgemeinschaft Wasserwerke Bodensee-Rhein Jahresbericht 2007, AWBR, Freiburg, Germany, 37-66, 2008.

Haralampides, K., McCorquodale, J. A., and Krishnappan, B. G.: Deposition Properties of Fine Sediment, J. Hydraul. Eng., 129, 3, 230-234, 2003.

He, Q. and Walling, D. E.: Spatial variability of the particle size composition of overbank floodplain deposits, Water Air Soil Poll., 99, 71-80, 1997.

Hilscherova, K., Dusek, L., Kubik, V., Cupr, P., Hofman, J., Klanova, J., and Holoubek, I.: Redistribution of organic pollutants in river sediments and alluvial soils related to major floods, J. Soils Sed., 7, 167-177, 2007.

Hollert, H., Dürr, M., Erdinger, L., and Braunbeck, T.: Cytotoxicity of settling particulate matter (SPM) and sediments of the Neckar river (Germany) during a winter flood, Environ. Toxicol. Chem., 19, 528-534, 2000.

Hollert, H., Haag, I., Dürr, M., Wetterauer, B., Holtey-Weber, R., Kern, U., Westrich, B., Färber, H., Erdinger, L., and Braunbeck, T.: Investigations of the ecotoxicological hazard potential and risk of erosion of contaminated sediments in lock-regulated rivers, Z. Umweltchem. Ökotox., 15, 5-12, 2003.

Hollert, H., Duerr, M., Haag, I., Wölz, J., Hilscherova, K., Blaha, L., and Gerbersdorf, S.: Influence of hydrodynamics on sediment ecotoxicity, in: Sediment dynamics and pollutant mobility in rivers, edited by: Westrich, B. and Förstner, U., Springer, 
Heidelberg, Germany, 401-416, 2007.

Howard, A. D.: Modelling Channel Migration and Floodplain Sedimentation in Meandering Streams, in: Lowland Floodplain Rivers: Geomorphological Perspectives, edited by: Carling, P. A., Petts, G. E., John Wiley \& Sons Ldt., Chichester, UK, 1562, 1992.

HVZ Hochwasser-Vorhersage-Zentrale Baden-Wuerttemberg, Pegel Maxau: http://www.hvz.baden-wuerttemberg.de/, access: 22. Dezember 2008.

Kennedy, S. W., Lorenzen, A., and Norstrom, R. J.: Chicken embryo hepatocyte bioassay for measuring cytochrome P4501Abased 2,3,7,8-tetrachlorodibenzo-p-dioxin equivalent concentrations in environmental samples, Environ. Sci. Technol., 30, 706715, 1996.

Keiter, S., Grund, S., Van Bavel, B., Hagberg, J., Engwall, M., Kammann, U., Klempt, M., Manz, W., Olsman, H., Braunbeck, T., and Hollert, H.: Activities and identification of aryl hydrocarbon receptor agonists in sediments from the Danube river, Anal. Bioanal. Chem., 390, 2009-2019, 2008.

Keiter, S., Rarstall, A., Kosmehl, T., Wurm, K., Erdinger, L., Braunbeck, T. and Hollert, H.: Ecotoxicological assessment of sediment, suspended matter and water samples in the upper Danube river, Environ. Sci. Pollut. Res., 13, 308-319, 2006.

Kosmehl, T., Krebs, F., Manz, W., Erdinger, L., Braunbeck, T., and Hollert, H.: Comparative genotoxicity testing of Rhine River sediment extracts using the comet assay with permanent fish cell lines (RTG-2 and RTL-W1) and the Ames test, J. Soils Sediment, 4, 84-94, 2004.

Kosmehl, T., Krebs, F., Manz, W., Braunbeck, T. and Hollert, H.: Differentiation between bioavailable and total hazard potential of sediment-induced DNA fragmentation as measured by the comet assay with zebrafish embryos, J. Soils Sediment, 7, 377-387, 2007.

Klee, N., Gustavsson, L. K., Kosmehl, T., Engwall, M., Erdinger, L., Braunbeck, T., and Hollert, H.: Changes in toxicity and genotoxicity of industrial sewage sludge samples containing nitroand amino-aromatic compounds following treatment in bioreactors with different oxygen regimes, Environ. Sci. Pollut. Res., 11, 313-320, 2004.

Krishnappan, B. G. and Engel, P.: Critical shear stresses for erosion and deposition of fine suspended sediments of the Fraser river, in: Cohesive Sediments, edited by: Burt, N., Parker, R., and Watts, J., John Wiley \& Sons Ltd., Chichester, UK, 279-288, 1997.

Krone, R. B.: Sedimentation Revisited, in: Coastal and Estuarine Studies 42. Nearshore and Estuarine Cohesive Sediment Transport, American Geophysical Union, 1993.
Kuijper, C., Cornelisse, J. M., and Winterwerp, J. C.: Erosion and Deposition Characteristics of Natural Muds, Sediments from Loswal Noord, Report-Nr. PB93-230183, Waterloopkundig Lab. te Delft. Prepared for: Rijkswaterstaat, Delft. Reproduced by National Technical Information Service, US Department of Commerce, Springfield, VA, USA, 21 pp., 1991.

Lorenzen, A. and Kennedy, S. W.: A fluorescence-based protein assay for use with a microplate reader, Anal. Biochem., 214, 346348, 1993.

Lübcke-Von Varel, U., Streck, G., and Brack, W.: Automated fractionation procedure for polycyclic aromatic compounds in sediment extracts on three coupled normal-phase high-performance liquid chromatography columns, J. Chromatogr. A, 1185, 31-42, 2008.

Maier, M., Kuehlers, D., Brauch, H.-J., Fleig, M., Maier, D., Jirka, G. H., Mohrlock, U., Bethge, E., Bernhart, H. H., Lehmann, B., Hillebrand, G., Wölz, J., and Hollert, H.: Flood retention and drinking water supply - Preventing conflicts of interest, J. Soils Sed., 6, 113-114, 2006.

Maier, D., Maier, M., Fleig, M.: Schwebstoffuntersuchungen im Rhein, in: AWBR Arbeitsgemeinschaft Wasserwerke BodenseeRhein Jahresbericht 1997, AWBR, St. Gallen, Switzerland, 137152, 1998.

Perez, S., Reifferscheid, G., Eichhorn, P. and Barcelo, D.: Assessment of the mutagenic potency of sewage sludges contaminated with polycyclic aromatic hydrocarbons by an Ames Fluctuation assay, Environ. Toxicol. Chem., 22, 2576-2584, 2003.

Pizzuto, J. E.: Sediment diffusion during overbank flows. Sedimentology, 34, 301-317, 1987.

Routledge, E. and Sumpter, J. P.: Estrogenic activity of surfactants and some of their degradation products assessed using a recombinant yeast screen, Environ. Toxicol. Chem., 15, 241-248, 1996.

Stronkhorst, J. and Van Hattum, B.: Contaminants of concern in Dutch marine harbor sediments, Arch. Environ. Contam. Toxicol., 45, 306-316, 2003.

Walling, D. E. and Bradley, S. B.: Rates and Patterns of Contemporary Floodplain Sedimentation: A Case Study of the River Culm, Devon, UK, GeoJournal, 19(1), 53-62, 1989.

Wang, J. S. Y and Narasimhan T. N.: Hydrological mechanisms governing fluid flow in a partially saturated, fractured, porous medium, Water Resour. Res., 21, 1861-1874, 1985

Wölz, J., Engwall, M., Maletz, S., Olsman, H., Van Bavel, B., Kammann, U., Klempt, M., Braunbeck, T., and Hollert, H.: Changes in toxicity and Ah receptor agonist activity of suspended particulate matter during flood events at the rivers Neckar and Rhine - A mass balance approach using in vitro methods and chemical analysis, Environ. Sci. Pollut. R., 15, 536-553, 2008. 